\title{
Stratospheric BrO abundance measured by a balloon-borne submillimeterwave radiometer
}

\author{
R. A. Stachnik ${ }^{1}$, L. Millán ${ }^{1}$, R. Jarnot ${ }^{1}$, R. Monroe $^{1}$, C. McLinden ${ }^{2}$, S. Kühl ${ }^{3}$, J. Puksīe ${ }^{3}$, M. Shiotani ${ }^{4}$, M. Suzuki ${ }^{5}$, \\ Y. Kasai ${ }^{6}$, F. Goutail ${ }^{7}$, J. P. Pommereau ${ }^{7}$, M. Dorf ${ }^{8}$, and K. Pfeilsticker ${ }^{8}$ \\ ${ }^{1}$ Jet Propulsion Laboratory, California Institute of Technology, Pasadena CA, 91109, USA \\ ${ }^{2}$ Air Quality Research Division, Environment Canada, Toronto, Ontario, Canada \\ ${ }^{3}$ MPI for Chemistry, Satellite Remote Sensing, Mainz, Germany \\ ${ }^{4}$ Research Institute for Sustainable Humanosphere, Kyoto University, Uji, Japan \\ ${ }^{5}$ ISS Science Project Office, Institute of Space and Astronautical Science, Japan Aerospace Exploration Agency, \\ Sagamihara, Japan \\ ${ }^{6}$ National Institute of Information and Communications Technology, Koganei, Japan \\ ${ }^{7}$ LATMOS, Centre National de la Recherche Scientifique, Universite Versailles Saint-Quentin, Guyancourt, France \\ ${ }^{8}$ Institut für Umweltphysik, University of Heidelberg, Heidelberg, Germany \\ Correspondence to: R. A. Stachnik (robert.a.stachnik@jpl.nasa.gov)
}

Received: 26 June 2012 - Published in Atmos. Chem. Phys. Discuss.: 6 November 2012

Revised: 23 February 2013 - Accepted: 25 February 2013 - Published: 22 March 2013

\begin{abstract}
Measurements of mixing ratio profiles of stratospheric bromine monoxide $(\mathrm{BrO})$ were made using observations of $\mathrm{BrO}$ rotational line emission at $650.179 \mathrm{GHz}$ by a balloon-borne SIS (superconductorinsulator-superconductor) submillimeterwave heterodyne limb sounder (SLS). The balloon was launched from Ft. Sumner, New Mexico $\left(34^{\circ} \mathrm{N}\right)$ on 22 September 2011. Peak mid-day $\mathrm{BrO}$ abundance varied from $16 \pm 2 \mathrm{ppt}$ at $34 \mathrm{~km}$ to $6 \pm 4 \mathrm{ppt}$ at $16 \mathrm{~km}$. Corresponding estimates of total inorganic bromine $\left(\mathrm{Br}_{\mathrm{y}}\right)$, derived from $\mathrm{BrO} \mathrm{vmr}$ (volume mixing ratio) using a photochemical box model, were $21 \pm 3$ ppt and $11 \pm 5 \mathrm{ppt}$, respectively. Inferred $\mathrm{Br}_{\mathrm{y}}$ abundance exceeds that attributable solely to decomposition of long-lived methyl bromide and other halons, and is consistent with a contribution from bromine-containing very short lived substances, $\mathrm{Br}_{\mathrm{y}}^{\mathrm{VSLS}}$, of $4 \mathrm{ppt}$ to $8 \mathrm{ppt}$. These results for $\mathrm{BrO}$ and $\mathrm{Br}_{\mathrm{y}}$ were compared with, and found to be in good agreement with, those of other recent balloon-borne and satellite instruments.
\end{abstract}

\section{Introduction}

Stratospheric bromine contributes to ozone loss through halogen catalyzed cycles analogous to stratospheric chlorine chemistry, except that the bromine cycles have a significantly greater potential to deplete ozone (Daniel et al., 1999). In the daytime upper stratosphere, $\mathrm{BrO}$ is the most abundant of the inorganic bromine species comprising up to $70 \%$ of $\mathrm{Br}_{\mathrm{y}}$, where

$\mathrm{Br}_{\mathrm{y}}=\mathrm{BrO}+\mathrm{HBr}+\mathrm{Br}+\mathrm{HOBr}+\mathrm{BrONO}_{2}+\mathrm{BrCl}$

Stratospheric $\mathrm{Br}_{\mathrm{y}}$ results from photodecomposition of naturally-occurring and anthropogenic bromine-containing source gases transported from the troposphere into the stratosphere. Although the total bromine loading of the stratosphere has declined by $1 \% \mathrm{yr}^{-1}$ since 2001 (Dorf et al., 2006b; Hendrick et al., 2008; WMO, 2011) due to reductions in surface emissions of $\mathrm{CH}_{3} \mathrm{Br}$ and other halons with long photochemical lifetimes, some uncertainty remains in the quantitative closure of $\mathrm{Br}_{\mathrm{y}}$ budget. Recent balloon-borne and satellite observations of $\mathrm{BrO}$ abundance indicate that $\mathrm{Br}_{\mathrm{y}}$ levels in the mid- and lower stratosphere exceed that estimated by models based solely on long-lived organic bromine surface source gases (Wamsley et al., 1998; Salawitch et al., 2005). 
The additional source of $\mathrm{Br}_{\mathrm{y}}$ needed to reconcile the stratospheric bromine budget is generally understood to be from decomposition of naturally occurring brominecontaining source gases with very short photochemical lifetimes (VSLS) such as $\mathrm{CHBr}_{3}, \mathrm{CH}_{2} \mathrm{BrCl}$, and $\mathrm{CH}_{2} \mathrm{BrCH}_{2} \mathrm{Br}$, with current estimates of $\mathrm{Br}_{\mathrm{y}}^{\mathrm{VSLS}}$ ranging from 2 to $8 \mathrm{ppt}$ (Salawitch et al., 2005; WMO, 2011; Brinckmann et al., 2012).

In situ measurements of $\mathrm{BrO}$ and total bromine in the stratosphere date from the early 1980's (Berg et al., 1980, reviewed in Brune and Stimpfle, 1993). More recently, an extensive series of $\mathrm{BrO}$ and $\mathrm{Br}_{\mathrm{y}}$ profiles, spanning several years and a range of season and latitude, were reported by (Dorf et al., 2006b) from balloon flights of the LPMA/DOAS (Limb Profile Monitor of the Atmosphere/Differential Optical Absorption Spectroscopy) instrument, the SAOZ-BrO (Systeme d'Analyse par Observation Zenithale) balloonborne spectrometer (Pundt et al., 2002), and the in situ UV resonance fluorescence BrO instrument (Woyke et al., 1999). Both LPMA/DOAS and SAOZ-BrO measure BrO by UV absorption of direct sunlight.

Global-scale observations of stratospheric $\mathrm{BrO}$ have been made by four satellite instruments.

SCIAMACHY (Scanning Imaging Absorption Spectrometer for Atmospheric Chartography) (Bovensmann et al., 1999) on the sun-synchronous Envisat, in limb mode, provided altitude profiles of $\mathrm{BrO}$ from measurement of scattered sunlight. SCIAMACHY was operational from 2002 until the loss of Envisat in April 2012. BrO profiles applied in this study are from MPI for Chemistry, Mainz. The retrieval is performed in the wavelength range from $338-357.25 \mathrm{~nm}$. For details, see Kühl et al. (2008) and Puķite et al. (2010).

Daily zonal mean $\mathrm{BrO}$ profiles, covering 16 to $36 \mathrm{~km}$ altitude, are measured by the Optical Spectrograph and Infra Red Imager System (OSIRIS) instrument on the Odin spacecraft (McLinden et al., 2010). Odin was launched in February 2001 into a $600 \mathrm{~km}$ circular, sun synchronous, near terminator orbit at an inclination of $97.8^{\circ}$ and an ascending node at 1800 local solar time (LST). BrO profiles are derived from observation of spectrally dispersed, limb scattered sunlight (346.0-376.6 $\mathrm{nm}$ wavelength range) from the upper troposphere into the lower mesosphere by the OSIRIS optical spectrograph.

The Microwave Limb Sounder (MLS), a millimeter and submillimeterwave heterodyne receiver on the EOS Aura platform, has been in operation since August 2004 and derives vertical profiles of $\mathrm{BrO}$ and other gases from limb thermal emission spectra. Aura is in sun-synchronous $98^{\circ}$ inclination orbit with ascending node equator crossing at approximately 01:45 p.m. local time. MLS BrO profiles are derived from ${ }^{81} \mathrm{BrO}$ rotational line emission at $625 \mathrm{GHz}$ and $650 \mathrm{GHz}$ (Waters et al., 2006; Kovalenko et al., 2007), as measured by the SLS in this study.

The Superconducting Submillimeter-wave Limb Emission Sounder (SMILES) (Masuko et al., 2002; Kikuchi et al.,
2010) measured $\mathrm{BrO}$ abundance in the middle atmosphere from the Japanese Experiment Module (JEM) of the International Space Station (ISS) from 12 October 2009 to 21 April 2010. The SMILES instrument, like Aura MLS, Odin/SMR and the balloon SLS, is a submillimeterwave heterodyne receiver system. The SMILES optics include a single sideband (SSB) filter to separate upper and lower sideband signals while MLS and SLS are double sideband (DSB) receivers. JEM/SMILES was the first space application of sensitive $4 \mathrm{~K}$ cooled SIS receiver technology mixers and HEMT (high electron mobility transistor) amplifiers for Earth atmospheric observation. The ISS orbit is non-sun-synchronous at $58^{\circ}$ inclination. SMILES observation frequency bands are 624.32$626.32 \mathrm{GHz}$ and $640.12-650.32 \mathrm{GHz}$, which cover the same $\mathrm{BrO}$ emission lines as Aura MLS and SLS.

\section{Observations and analysis}

Data presented here are from a high altitude balloon flight of the Jet Propulsion Laboratory (JPL) Submillimeterwave Limb Sounder (SLS) instrument from the Columbia Scientific Balloon Facility site at Ft. Sumner, New Mexico, USA $\left(34^{\circ} \mathrm{N}, 104^{\circ} \mathrm{W}\right)$. On-board the gondola, in addition to the SLS, were the JPL MkIV solar occultation Fourier transform infrared spectrometer (Toon, 1991) and in situ $\mathrm{O}_{3}$ sensor (Proffitt and McLaughlin, 1983). The balloon was launched on 22 September 2011, reached float altitude of approximately $39 \mathrm{~km}$ at 13:30 local time and remained above $37 \mathrm{~km}$ through the flight until flight termination the next day. Spectra covering the $\mathrm{BrO}$ band were collected upon reaching float altitude on 22 September until 04:00 on 23 September.

The Submillimeter Limb Sounder is a heterodyne radiometer that measures molecular rotational thermal emission spectra from a limb observing geometry. The SLS has been flown on numerous middle and high latitude flights since 1991 (Stachnik et al., 1992, 1999). Measured gases include $\mathrm{ClO}, \mathrm{O}_{3}, \mathrm{HCl}, \mathrm{N}_{2} \mathrm{O}, \mathrm{HO}_{2}$, and $\mathrm{HNO}_{3}$. In 2004, the instrument was upgraded with a superconductor-insulatorsuperconductor (SIS) mixer improving receiver sensitivity by 20 times compared to that with the Schottky diode mixer used on earlier flights. Spectrometers were also upgraded from analog filterbanks to a single digital polyphase filterbank spectrometer that provides uniform channels with high spectral resolution and significantly improved gain stability. Figure 1 is a block diagram of the radiometer. Radiance from the atmospheric limb, sky cold reference and warm calibration reference are selected by a scanning $30 \mathrm{~cm}$ diameter primary antenna and scan plate. The measured field-of-view is approximately $0.6^{\circ}$ full width at half maximum. The double sideband down converter is a quasi-optic coupled SIS NbTiN junction mixer (Zmuidzinas, 1992). The tunable local oscillator $(620 \mathrm{GHz}$ to $680 \mathrm{GHz})$ is generated by a synthesizer, amplifier, multiplier and coupled to the mixer by a Mylar beamsplitter. The SIS junction and HEMT low noise 


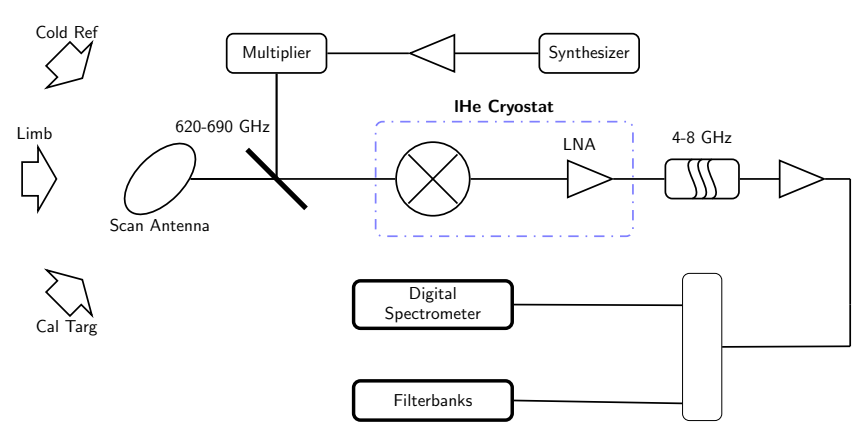

Fig. 1. Diagram of the SLS instrument. Atmospheric radiance is collected by a scanning antenna system, combined by a Mylar beam splitter with a frequency tunable local oscillator, downconverted in an SIS mixer. The IF signal is amplified, filtered, downconverted in a second heterodyne stage to the input frequency range of the digital and analog spectrometers.

amplifier (Ward et al., 2003; Ward, 2003) are maintained at $4.2 \mathrm{~K}$ in a liquid helium cryostat. Following downconversion in the SIS mixer, the output intermediate frequency (IF) band $(4-7 \mathrm{GHz})$ is analyzed by the digital spectrometer.

The digital spectrometer (Fig. 2) deployed on SLS was instrumental in obtaining excellent data quality. A digital polyphase spectrometer was implemented in a Reconfigurable Open Architecture Computing Hardware (ROACH) digital signal processing board developed by the Berkeley CASPER project (Werthimer, 2011). Two 3 Gsps (gigasamples per second) analog to digital converter cards, sampling the IF down converted to base band at an aggregate rate of $6 \mathrm{Gsps}$, provided $3 \mathrm{GHz}$ of bandwidth with 8192 channels and frequency resolution of $375 \mathrm{kHz}$. For the measurements discussed here channels were co-added to provide a reduced data rate due to the limited on-board data storage system, reducing the spectral resolution to $750 \mathrm{kHz}$. The polyphase FFT implementation provides channels with steeper response rolloff than that of either autocorrelator or standard FFT digital spectrometers. A Power PC interfaced to the Virtex 5 field programmable gate array (FPGA) on the CASPER board performs additional data processing, telemetry down-link, and data storage on a USB flash drive.

\section{Radiometric calibration}

Radiometric calibration was performed as described for earlier versions of the SLS instrument (Stachnik et al., 1992, 1999). The spectrometer response at each frequency $i, C^{i}$, is proportional to atmospheric radiance plus receiver noise power. As part of each limb scan sequence, the scan plate is rotated to view cold sky radiance $\left(+45^{\circ}\right.$ elevation angle) and an on-board ambient temperature calibration black-body.

For each spectrometer channel,

$$
C_{\text {limb } \mid \text { sky } \mid \text { cal }}^{i}=g^{i} \times\left(P_{\text {limb } \mid \text { sky } \mid \text { cal }}^{i}+P_{\text {receiver }}^{i}\right)
$$

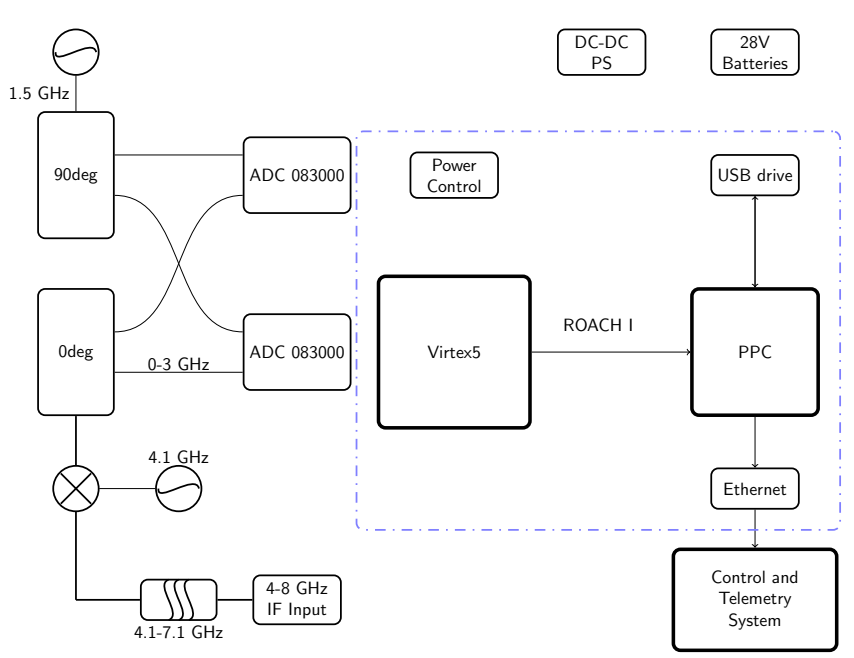

Fig. 2. Diagram of the digital spectrometer sub-system. Two interleaved National ADC083000 digitizers sample the input signal at $6 \mathrm{G}$ samples $\mathrm{s}^{-1}$. Signal bitstream is converted to a power spectrum by an algorithm implemented in the Xilinx Virtex 5 FPGA. Code in a PowerPC collects spectra data, stores data onboard in a flashdrive, and transmits a real-time compressed sample of spectra to the ground.

where $C_{\text {limb|sky|cal }}$ is the spectrometer response with scan plate viewing limb, sky, or cal and $P_{\text {receiver }}^{i}$ is the noise power contributed internally by the receiver system from the SIS mixer, amplifiers, second heterodyne stage and spectrometer. Limb-sky difference radiance, $P_{\text {limb-sky }}^{i}$ for channel $i$, is then

$P_{\text {limb-sky }}^{i}=\left(C_{\text {ant }}^{i}-C_{\text {sky }}^{i}\right) / g^{i}(t)$

Gain coefficients, $g^{i}(t)$ (counts/Kelvin), drift with time due to changes in instrument temperature, local oscillator drive power and ambient pressure, and are determined by linear interpolation of the instantaneous gain, $g^{i}\left(\mathrm{cal}_{n}\right)$, measured during the ambient temperature calibration target scene at $t=\mathrm{cal}_{n}$ for limb scan $n$.

$g^{i}\left(\mathrm{cal}_{n}\right)=\frac{C_{\mathrm{cal}}^{i}-C_{\mathrm{sky}}^{i}}{P_{\mathrm{cal}}-P_{\mathrm{sky}}^{i}}$

The calibration target black-body radiant power, $P_{\text {cal }}$, in Kelvins, is the Planck temperature evaluated at $650 \mathrm{GHz}$. The "sky" reference temperature, $P_{\text {sky }}^{i}$, is essentially the $3 \mathrm{~K}$ cosmic background brightness, except near the center of strong atmospheric emission lines where the residual air mass above the balloon altitude adds non-negligible atmospheric radiance of, maximally, $5 \%$ of $P_{\text {cal }}$ for balloon altitude of $38 \mathrm{~km}$. To reduce systematic gain error, an atmospheric radiative transfer model (discussed in Sect. 4) with climatological trace gas concentrations is used to estimate $P_{\text {sky }}^{i}$. 


\section{Profile retrieval}

Mixing ratio profiles of atmospheric trace gases are derived from the SLS calibrated radiances, $P_{\text {limb-sky }}^{i}$, through an instrument radiance "forward" model that calculates the expected radiances from an input atmospheric state model. Preflight measurements of channel shape, sideband ratio, antenna field-of-view are used, together with balloon height and radiosonde temperature profiles, in the forward model to calculate and convolve ray radiances. The 1-dimensional atmospheric state model parameterizes constituent concentration with altitude as a set of triangular basis functions on $2 \mathrm{~km}$ centers from the surface to $100 \mathrm{~km}$. The atmospheric model currently includes approximately 180 of the likely "most significant" gases and isotopologues for which spectroscopic data is available. Pressure, temperature and water vapor profiles in the model are from local radiosondes launched within the duration of the balloon flight. Ray radiance is calculated at each frequency by line by line summation of Voigt lineshape contributions along a path from balloon through the model atmosphere for each channel frequency element $r^{i}(v)$ and for each antenna scan plate elevation angle. Spectroscopic and partition function data are from the JPL catalog (Pickett et al., 1998). Expressions for $\mathrm{N}_{2}$ and $\mathrm{O}_{2}$ collision-induced absorption and water vapor continuum are from (Goyette and DeLucia, 1990; Rosenkranz, 1998). Instrumental field-of-view smearing is incorporated by convolving the ray radiances with a Gaussian beam shape function matched to the measured beam parameters.

Mixing ratio profiles are estimated from measured radiances by the linear optimal estimation retrieval scheme (Houghton et al., 1984; Rodgers, 2000). Briefly, optimal estimation retrieval is essentially a least-squares fit of observed radiances, weighted by observation uncertainty (covariance), to a linearized atmospheric radiance model, $\boldsymbol{y}-\boldsymbol{y}_{0}=\mathbf{K}\left(\boldsymbol{x}-\boldsymbol{x}_{0}\right)$, where the matrix $\mathbf{K}$ of partial derivatives relates the vector of radiances $\boldsymbol{y}$ to the vector of parameters in atmospheric model state vector, $\boldsymbol{x}$ about linearization point $\left(\boldsymbol{x}_{0}\right), \boldsymbol{y}_{0}$ is the calculated radiance for parameter vector $\boldsymbol{x}_{0}$. The partial derivative matrix is calculated by finite difference in the forward model along with the radiances. The inversion is stabilized by addition of 'virtual' measurements derived from atmospheric model initial, a priori, state. The retrieval result is bound to the a priori where measurements are either absent or excessively noisy. The minimum variance estimate of the atmospheric state vector is

$$
\boldsymbol{\Delta} \boldsymbol{x}=\boldsymbol{x}-\boldsymbol{x}_{0}=\mathbf{S}_{\mathrm{a}} \mathbf{K}^{T}\left(\mathbf{K S}_{\mathrm{a}} \mathbf{K}^{T}+\mathbf{S}_{\epsilon}\right)^{-1} \boldsymbol{\Delta} \boldsymbol{y}
$$

where $\boldsymbol{y}-\boldsymbol{y}_{0}=\boldsymbol{\Delta} \boldsymbol{y}$ is the vector of measurement residuals, $\mathbf{S}_{\mathrm{a}}$ is the covariance matrix of the a priori, $\mathbf{S}_{\epsilon}$ is the diagonal measurement covariance and $\boldsymbol{x}_{0}$ is the a priori atmospheric state.

\section{Retrieval precision and accuracy}

The overall uncertainty in retrieved $\mathrm{BrO}$ profiles has contributions from radiometric precision from thermal noise and systematic errors from radiance calibration error, standing wave spectral artifacts, antenna pointing, spectroscopic parameters used in the forward radiance model and retrieval error. Radiometric precision is limited by thermal noise

$$
\Delta T=\frac{T_{\mathrm{sys}}}{\sqrt{B \tau}}
$$

where $T_{\text {sys }}$ is the sum of atmospheric radiance, $T_{\text {cal|limb|sky, }}$ and total receiver noise, $T_{\text {receiver }}$, expressed in Kelvins; $B$ is the effective measurement noise bandwidth in $\mathrm{s}^{-1}$ and $\tau$ is the integration time in seconds. $T_{\text {receiver for the SIS re- }}$ ceiver is approximately $280 \mathrm{~K}$ averaged across the IF band pass. Thermal background atmospheric radiance varies with tangent height from a few $\mathrm{K}$ at $38 \mathrm{~km}$ to $250 \mathrm{~K}$ when scanning down to the lowermost stratosphere. The precision in retrieved parameters, as limited by radiometric noise, is given by

$\mathbf{S}=\left(\mathbf{K}^{T} \mathbf{S}_{\epsilon}^{-1} \mathbf{K}+\mathbf{S}_{\mathrm{a}}^{-1}\right)^{-1}$

which relates measurement covariance, $\mathbf{S}_{\epsilon}$ to uncertainty in the retrieved parameter covariance. Diagonal elements of $\mathbf{S}$ are the estimated uncertainties in the retrieved atmospheric state vector elements. Systematic uncertainty in the $\mathrm{BrO} v \mathrm{mr}$ retrieval due to standing waves and other spectral artifacts, remaining after day-night differencing, are estimated from the partial derivative matrix and the vector of post-retrieval residuals. Overall radiance calibration scaling error, due to uncertainty in the calibration target effective black body temperature, is approximately $2 \%$ as estimated by comparison of measured and calculated radiance at the center of opticallythick $\mathrm{O}_{3}$ lines in the receiver band pass. The retrieval error budget for retrievals using flight-averaged spectra is summarized in Fig. 3 which shows contributions from radiometric noise, calibration uncertainty and post-retrieval residuals in comparison with the apriori covariance and retrieval profile. The SLS instrument pointing is derived from an onboard solid-state gyroscope, inclinometer, and magnetometer package accurate to approximately $0.1^{\circ}$ which implies a height uncertainty of $0.6 \mathrm{~km}$ at $30 \mathrm{~km}$ tangent height. In post-flight processing, the pointing uncertainty was reduced to approximately $0.3 \mathrm{~km}$ by fitting a pointing offset to match the sharp onset of measured and calculated radiance at tangent heights below the tropopause.

\section{Measurements}

\subsection{BrO spectroscopy}

The rotational emission spectrum of ${ }^{81} \mathrm{BrO}$ in its ground vibrational and electronic state consists of $\Lambda$-doubled and hyperfine split lines spaced at $\sim 25 \mathrm{GHz}$ (Pickett et al., 1998). 


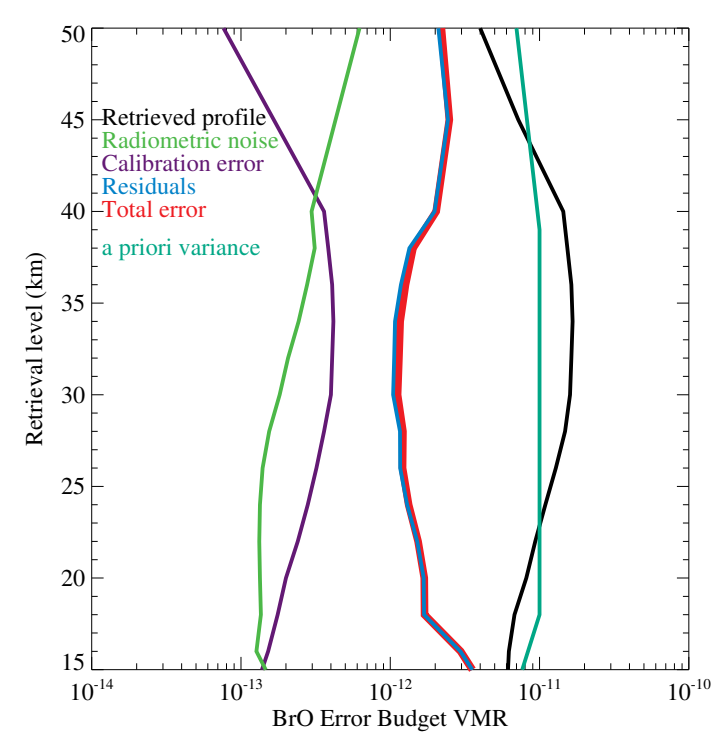

Fig. 3. The retrieval error budget showing total retrieval error and contributions from radiometric noise for flight-averaged spectra, calibration uncertainty and post-retrieval residuals compared with the apriori covariance and retrieved profile.

Two lines, the $J=\frac{49}{2}-\frac{47}{2}$ at 624.768 and the $J=\frac{51}{2}-\frac{49}{2}$ at $650.179 \mathrm{GHz}$ are within the SLS local oscillator frequency tuning range. Although the $\mathrm{BrO}$ line near $624 \mathrm{GHz}$ has fewer spectroscopic interferences, the $\mathrm{BrO} J=\frac{51}{2}-\frac{49}{2}$ feature near $650.179 \mathrm{GHz}$ enables simultaneous measurement of the ${ }^{35} \mathrm{ClO}$ lines at $649.4 \mathrm{GHz}, 3 \mathrm{HO}_{2}$ lines and $2 \mathrm{O}_{3}$ emission lines within the IF band pass of the SLS instrument (see Fig. 4). Additionally, the $\mathrm{BrO}$ feature at $650 \mathrm{GHz}$ is also observed by the Aura EOS MLS and ISS JEM-SMILES instruments. This provides the opportunity for direct spectral comparison. Line parameters, pressure line width and temperature dependencies for these transitions are from recent studies by Yamada et al. (2003) and Drouin et al. (2001).

$\mathrm{BrO}$ profiles are retrieved from the average of daytime (solar zenith angle less than $\sim 85^{\circ}$ ) limb scan spectra recorded between 13:30 and and 18:00 local time. Spectra cover the tangent height range, in $2 \mathrm{~km}$ steps, from balloon float at $39.6 \mathrm{~km}$ to below the tropopause height where the limb path becomes opaque due to water vapor absorption. Figure 4 shows a sample of the flight-average full $3 \mathrm{GHz}$ bandwidth spectra corresponding to limb tangent heights of 38, 36, 34, $30 \mathrm{~km}$. Prominent, near $4500 \mathrm{MHz} \mathrm{IF}$, in these spectra are two optically thick features corresponding to $\mathrm{O}_{3}$ lines at $638.903 \mathrm{GHz}$ and at $647.839 \mathrm{GHz}$ in the receiver lower and upper sidebands, respectively. These lines of nearly equivalent strength provide a convenient in-flight high precision measure of the receiver sideband response ratio. As shown in Fig. 5, the ${ }^{81} \mathrm{BrO}$ emission line octet at $650.178 \mathrm{GHz}$ $\left(6730 \mathrm{MHz}\right.$ IF) appears on the shoulder of stronger $\mathrm{OO}^{17} \mathrm{O}$ lines in the same sideband and adjacent to another $\mathrm{O}_{3}$ feature.

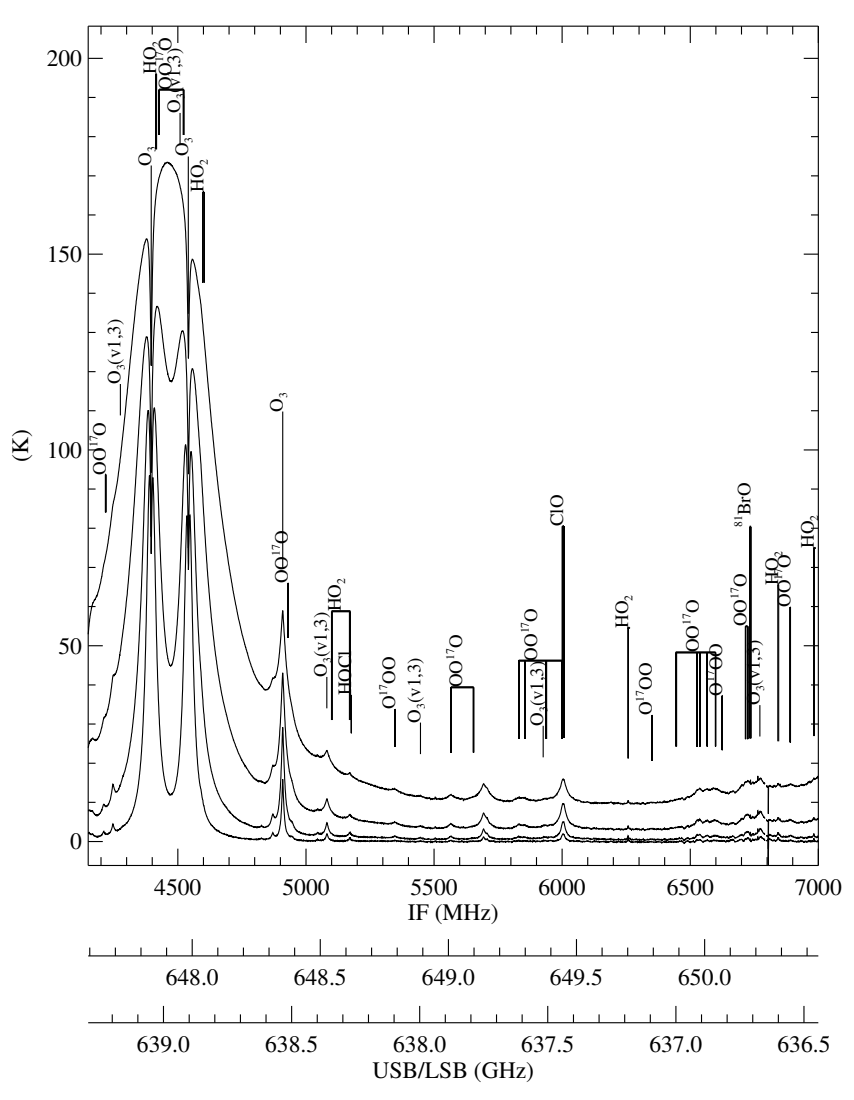

Fig. 4. Measured double-sideband emission daytime-average spectra with local oscillator frequency at $643.444 \mathrm{GHz}$. Sample spectra from the September 2011 balloon flight showing the full spectrometer bandwidth corresponding to limb tangent heights of 38, 36, 34 and $30 \mathrm{~km}$. Region containing the ${ }^{81} \mathrm{BrO}$ lines is at the far right. Abscissa scales show intermediate frequency (IF), and upper/lower sideband frequency prior to heterodyne downconversion.

The excellent dynamic range of the digital spectrometer is evident from Fig. 4 that shows a subset of limb spectra covering $180 \mathrm{~K}$ brightness range of atmospheric signals, Fig. 5 that shows a zoomed in region covering BrO, and Fig. 6 that shows the day minus night difference spectra with a full scale range of $0.3 \mathrm{~K}$. As these spectra are double-sideband, triple abscissa axes give intermediate frequency (IF), upper and lower sideband frequency prior to heterodyne downconversion. An additional property of the digital spectrometer is its ability to "tie together" contiguous channels due to the use of a common digitizer, which explains the excellent small signal performance of the measurement system, and which also allows a reduced chopping (Dicke switching) rate to be used with minimal impact to the quality of spectral contrast data.

Since $\mathrm{BrO}$ abundance exhibits a strong diurnal behavior forming $\mathrm{BrONO}_{2}$ rapidly following sunset, and $\mathrm{O}_{3}$ does not diurnally vary in the middle stratosphere, interfering $\mathrm{O}_{3}$ lines, residual standing-wave artifacts, other interferences and offsets were removed by subtracting, from the daytime spectra at each tangent height, corresponding averaged 


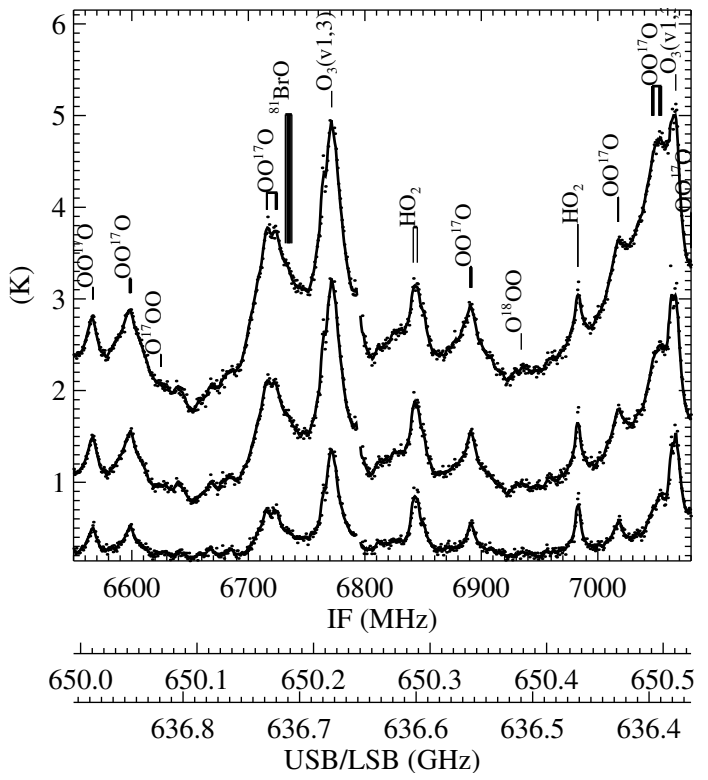

Fig. 5. Double sideband daytime-average emission spectra observed corresponding to limb tangent heights of 38,34 , and $32 \mathrm{~km}$ showing the region of ${ }^{81} \mathrm{BrO}$ and overlapping $\mathrm{O}_{3}$ lines. Abscissa scales show intermediate frequency (IF), and upper/lower sideband frequency prior to heterodyne downconversion.

nighttime spectra. Potential differences between daytime and nighttime $\mathrm{O}_{3}$ emission were monitored using the strong set of $\mathrm{O}_{3}$ lines near $4.5 \mathrm{GHz} \mathrm{IF}$ (see Fig. 4).

The nighttime average consists of spectra recorded between 23:00 (22 September) and 04:00 (23 September) local solar time at the position of the balloon. This procedure is particularly effective for balloon measurements since, in the absence of strong wind shear, the balloon platform, drifting with the local circulation, permits continuous (approximate) observation of a single air parcel. The SLS field-of-view is stabilized to a constant azimuthal direction by the gondola pointing system. Integration time varies with observation tangent height but averaged approximately $1100 \mathrm{~s}$ and $1200 \mathrm{~s}$ per day and nighttime spectrum for each tangent height bin, respectively.

The resulting day-night spectra, shown in Fig. 6, for limbpath tangent heights of $38,34,32$ and $28 \mathrm{~km}$ reveal a $200 \mathrm{mK}$ amplitude ${ }^{81} \mathrm{BrO}$ line and two prominent $\mathrm{HO}_{2}$ features also visible due to the diurnal variation of $\mathrm{HO}_{2}$ mid-stratosphere abundance. $\mathrm{BrO}$ and $\mathrm{HO}_{2}$ profiles were retrieved on a $2 \mathrm{~km}$ grid from the day-night spectra using the optimal estimation procedure. Synthetic day-night spectra, calculated using the retrieved $\mathrm{BrO}$ and $\mathrm{HO}_{2}$ profiles, are shown (red) in Fig. 6.

The retrieved $\mathrm{BrO}$ profile and estimated uncertainty are shown in Fig. 7 in comparison with a $\mathrm{BrO}$ profile from EOS MLS. BrO profile uncertainty, as described in Sect. 5, is the combined error from radiometric precision, calibration bias, pointing offset, and retrieval residuals. The variation of profile uncertainty with altitude can be explained as

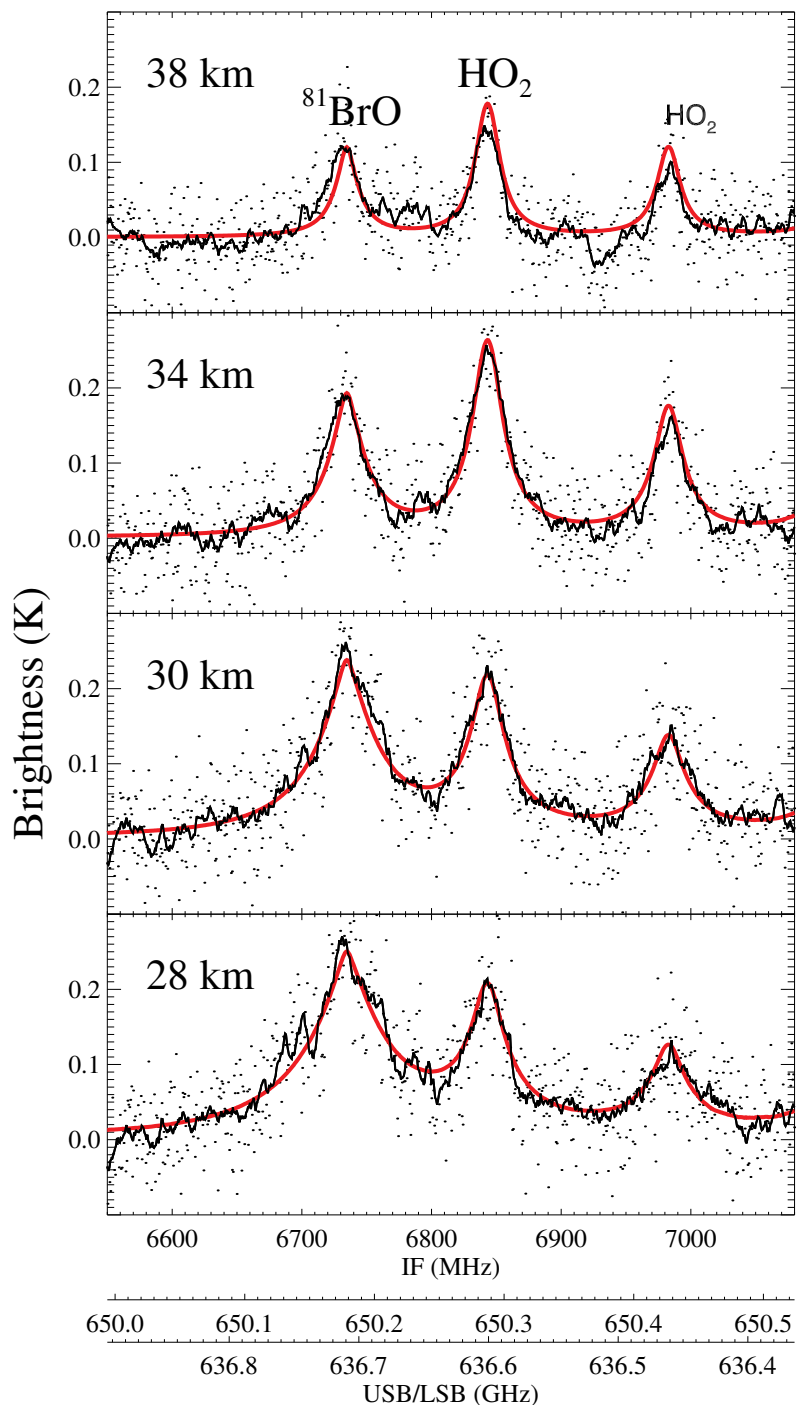

Fig. 6. Day-night difference emission spectra of the same spectral region shown in Fig. 5. Spectrometer data are shown at $750 \mathrm{kHz}$ (dots) resolution and boxcar smoothed (thick solid black line). Synthetic spectra calculated using retrieved $\mathrm{BrO}$ profiles are also plotted (red-solid). Abscissa scales show intermediate frequency (IF), and upper/lower sideband frequency prior to heterodyne downconversion. $\mathrm{HO}_{2}$ line occurring in lower sideband is indicated by the san-serif font.

follows. At heights near to and above the balloon float altitude $(\sim 38 \mathrm{~km})$, uncertainty increases as the instrumental observation path length decreases from a limb path length of $\sim 300 \mathrm{~km}$ to a much shorter upward slant path observing geometry $(\sim 50 \mathrm{~km})$. In the middle altitude range $(37 \mathrm{~km}$ to $25 \mathrm{~km}$ ), best sensitivity is achieved due to the low level of background radiance, minimal pointing error, and narrow tangent point beam-width. Below $25 \mathrm{~km}$, uncertainty increases due to increasing thermal noise from water vapor continuum emission, and effect of the propagation of gain error with increasing radiance background. 


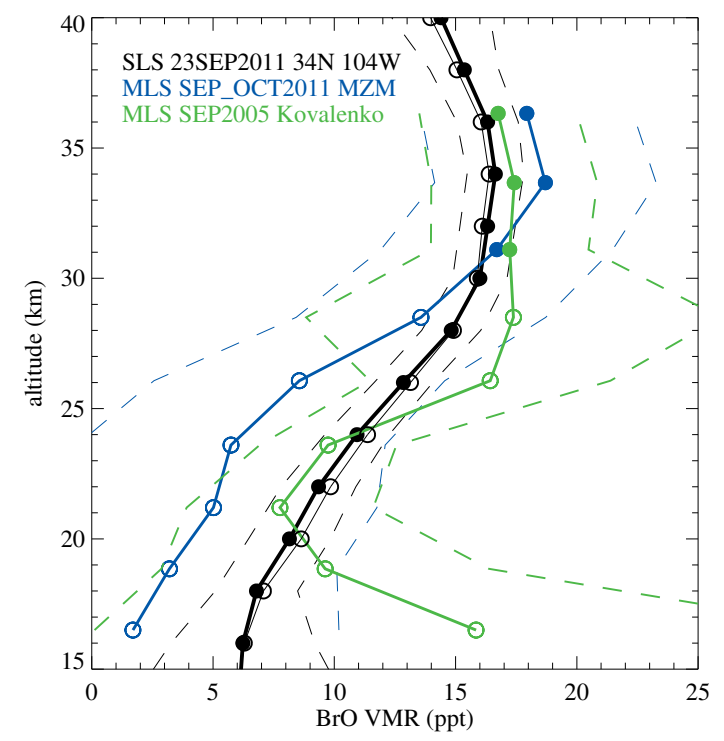

Fig. 7. SLS BrO profile (black) from the 09/23/2011 balloon flight compared with MLS. Black line open circles indicate SLS data adjusted to the local time of the MLS daytime overpass. The MLS BrO profile (blue-solid) is zonal mean $\left(25^{\circ} \mathrm{N}\right.$ to $\left.35^{\circ} \mathrm{N}\right)$ for the period 1 September 2011 through 31 October 2011. The MLS 2 month zonal mean averaged precision is indicated by the blue-dashed lines. The range of scientifically useful MLS measurements is 10 to $4.6 \mathrm{hPa}$ corresponding to approximately $30 \mathrm{~km}$ to $37 \mathrm{~km}$. Also shown (green dots-lines) is the MLS BrO profile for September 2005 from (Kovalenko et al., 2007) derived using a different retrieval procedure. Uncertainty range is indicated by the green dashed lines. The range of useful MLS measurements is indicated by solid circles for both data sets.

\subsection{Inferred $\mathrm{Br}_{\mathrm{y}}$}

$\mathrm{BrO}$, as the most abundant of inorganic bromine gases in the daytime stratosphere, provides the best indication of total $\mathrm{Br}_{\mathrm{y}}$. Since $\mathrm{BrO}$ is in rapid photochemical equilibrium with $\mathrm{BrONO}_{2}, \mathrm{Br}$, and $\mathrm{HOBr}$, the $\mathrm{BrO}$ comprises a variable fraction of $\mathrm{Br}_{\mathrm{y}}$ depending on local solar time, latitude, altitude, atmospheric composition and season.

Following previous approaches (Kovalenko et al., 2007; McLinden et al., 2010), we estimate $\mathrm{Br}_{\mathrm{y}}$ profile from measured $\mathrm{BrO}$ using a photochemical model. In this study, the University of California, Irvine photochemical box model (Prather, 1992; McLinden et al., 2000; Brohede et al., 2008) was used. The model was constrained to climatological profiles for $\mathrm{O}_{3}, \mathrm{NO}_{\mathrm{y}}, \mathrm{Cl}_{\mathrm{y}}, \mathrm{N}_{2} \mathrm{O}, \mathrm{CH}_{4}$ and $\mathrm{H}_{2} \mathrm{O}$. For the model $\mathrm{Br}_{\mathrm{y}}$ profile, the correlation from Wamsley et al. (1998), increased by an assumed VSLS bromine contribution of $6 \mathrm{ppt}$, was used. $\mathrm{Br}_{\mathrm{y}}$ was estimated using a simple linear scaling relationship between model and measured $\mathrm{BrO}$ and $\mathrm{Br}_{\mathrm{y}}$. At each altitude,

$\left[\mathrm{Br}_{\mathrm{y}}^{\text {measured }}\right]=\frac{\left[\mathrm{Br}_{\mathrm{y}}^{\text {model }}\right]}{\left[\mathrm{BrO}^{\text {model }}\right]}\left[\mathrm{BrO}^{\text {measured }}\right]$

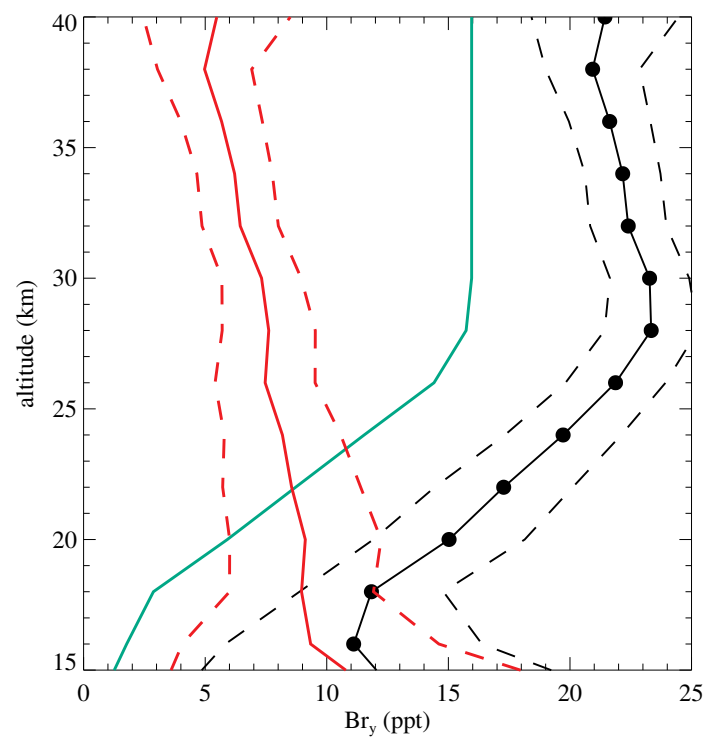

Fig. 8. $\mathrm{Br}_{\mathrm{y}}$ mixing ratio inferred from SLS measured $\mathrm{BrO}$ (black) using a photochemical box model. $\mathrm{Br}_{\mathrm{y}}$ uncertainty range (blackdashed) is the $\mathrm{BrO}$ uncertainty scaled by $\mathrm{Br}_{\mathrm{y}} / \mathrm{BrO}$ from the photochemical box model. Abundance of $\mathrm{Br}_{\mathrm{y}}$ from long-lived organic sources (cyan) is from Wamsley et al. (1998) scaled to $16 \mathrm{ppt}$ at peak. Estimated VSLS abundance (red, uncertainty as red-dashed) is $\mathrm{Br}_{\mathrm{y}}$ minus the estimate of inorganic bromine attributed to longlived bromine source gases.

Since $\mathrm{BrO}$ measurements are derived from day-night spectra, $\mathrm{BrO}^{\text {model }}$ is calculated from corresponding model daytime minus nighttime averaged differences. After sunset, $\mathrm{BrO}$ rapidly forms $\mathrm{BrONO}_{2}$ in the mid- and lower stratosphere so this diurnal correction to the modelled $\mathrm{BrO}$ is small (less than $0.5 \mathrm{ppt}$ ) below $38 \mathrm{~km}$. Applying Eq. (8) at each altitude to measured $\mathrm{BrO}$, gives an estimate of the $\mathrm{Br}_{\mathrm{y}}$ altitude profile which is shown plotted in Fig. 8. Uncertainty in the $\mathrm{Br}_{\mathrm{y}}$ estimate is simply scaled from that estimated for $\mathrm{BrO}$ and neglects biases that might be introduced by input parameters to the photochemical model. For example, a recent study by Kreycy et al. (2012) finds the ratio of photolysis to formation $(\mathbf{J} / \mathbf{k})$ for $\mathrm{BrONO}_{2}$ a factor of 1.69 larger than that indicated by the JPL-11 compilation (Sander et al., 2011) which could reduce the $\mathrm{Br}_{\mathrm{y}}$ estimated here by $1-2 \mathrm{ppt}$.

From the average $\mathrm{Br}_{\mathrm{y}}$ from $28 \mathrm{~km}$ to $38 \mathrm{~km}$, where uncertainty in measured $\mathrm{BrO}$ and sensitivity to photochemical model inputs are minimal, we derive estimated value for total inorganic bromine, $\mathrm{Br}_{\mathrm{y}}$, of $21 \pm 3$ ppt. The uncertainty in total $\mathrm{Br}_{\mathrm{y}}$ is from the extreme values plus estimated uncertainty of $\mathrm{Br}_{\mathrm{y}}$ within the $28 \mathrm{~km}$ to $38 \mathrm{~km}$ altitude range. We estimate the implied contribution to $\mathrm{Br}_{\mathrm{y}}$ from very short lived bromine organics by subtracting $\mathrm{Br}_{\mathrm{y}}$ attributed to $\mathrm{CH}_{3} \mathrm{Br}$ and other long-lived bromine source gases using the $\mathrm{Br}_{\mathrm{y}}-\mathrm{N}_{2} \mathrm{O}$ correlation expressions in Wamsley et al. (1998) scaled to $16 \mathrm{ppt}$ of $\mathrm{CH}_{3} \mathrm{Br}$ plus halon peak abundance (WMO, 2011) assuming age-of-air of $5 \mathrm{yr}$ and 2006 as the year of stratospheric 
entry. Comparison in Fig. 8 of total $\mathrm{Br}_{\mathrm{y}}$ to that from longlived bromine organics is consistent with a VSLS contribution of $6 \pm 4 \mathrm{ppt}$ above $28 \mathrm{~km}$. Below $28 \mathrm{~km}$, a slight increasing trend in estimated $\mathrm{Br}_{\mathrm{y}}^{\mathrm{VSLS}}$ to $8 \mathrm{ppt}$ at $16 \mathrm{~km}$ is evident but within the larger estimated uncertainty bounds for that altitude.

\subsection{Comparison with other measurements}

The Microwave Limb Sounder (MLS) instrument (Waters et al., 2006) on the EOS Aura satellite measures BrO abundance profiles also monitoring the $J=\frac{51}{2}-\frac{49}{2}$ rotational emission lines at $650.179 \mathrm{GHz}$. However, MLS uses a different local oscillator frequency $(642870.0 \mathrm{MHz})$ than the SLS balloon instrument $(643444.0 \mathrm{MHz})$ and therefore has different spectral interferences from the lines in the receiver opposite sideband. The MLS radiometric noise level necessitates significant spatial and temporal averaging to obtain comparable $\mathrm{BrO}$ mixing ratio precision (Kovalenko et al., 2007). Since the EOS-Aura MLS is in sun-synchronous orbit measuring at 13:45 and 01:45 local time for the ascending and descending parts of the orbit respectively, spectral interference due to ozone emission and other bias can be effectively removed by taking day-night (ascending-descending) differences of the retrieved $\mathrm{BrO}$ profiles. In Fig. 7, we compare the MLS BrO zonal $\left(25^{\circ} \mathrm{N}\right.$ to $\left.35^{\circ} \mathrm{N}\right)$ bi-monthly mean (blue line) of day-night retrieved profiles using the new algorithm described in Millán et al. (2012). The date range of MLS data is centered on the balloon flight date, 22 September 2011. The MLS retrieval profile precision bound for the bi-monthly mean is shown as blue-dashed lines. In Fig. 7, we also show the MLS BrO profile for September 2005 from Kovalenko et al. (2007) which was derived using a slightly different retrieval procedure. For both MLS retrieval cases, the pressure range over which the data are useful is $10 \mathrm{hPa}$ to $4.6 \mathrm{hPa}$ (approximately $30 \mathrm{~km}$ to $37 \mathrm{~km}$ ) which is indicated on the plot by closed circles, and open circles outside this range. Agreement between both MLS and SLS profiles is generally good and within the MLS precision bounds at all altitudes. In the region between $10 \mathrm{hPa}$ to $4.6 \mathrm{hPa}$, profiles agree to within 3 ppt.

Figure 9 shows the $\mathrm{Br}_{\mathrm{y}}$ profile (black line) inferred from the SLS BrO profile mixing ratio using the UC Irvine photochemical box model compared to $\mathrm{Br}_{\mathrm{y}}$ inferred from the MLS $\mathrm{BrO}$ average for 2005 using SLIMCAT and WACCM photochemical models (Millán et al., 2012). The range of scientifically useful MLS measurements (10 to $4.6 \mathrm{hPa}$ ) is indicated by solid circles. MLS and SLS Bry results are consistent in the upper stratosphere (above $6 \mathrm{hPa}$ ) finding total inorganic stratospheric bromine at approximately $21 \mathrm{ppt}$. Uncertainties in inferred $\mathrm{Br}_{\mathrm{y}}$ are indicated by dashed black and dashed red lines for SLS and MLS, respectively. For reference, the $\mathrm{Br}_{\mathrm{y}}$ estimated from long-lived organic gases from Wamsley et al. (1998) scaled to $16 \mathrm{ppt}$ for an age-of-air of $5 \mathrm{yr}$ (2006) is also plotted (cyan curve).

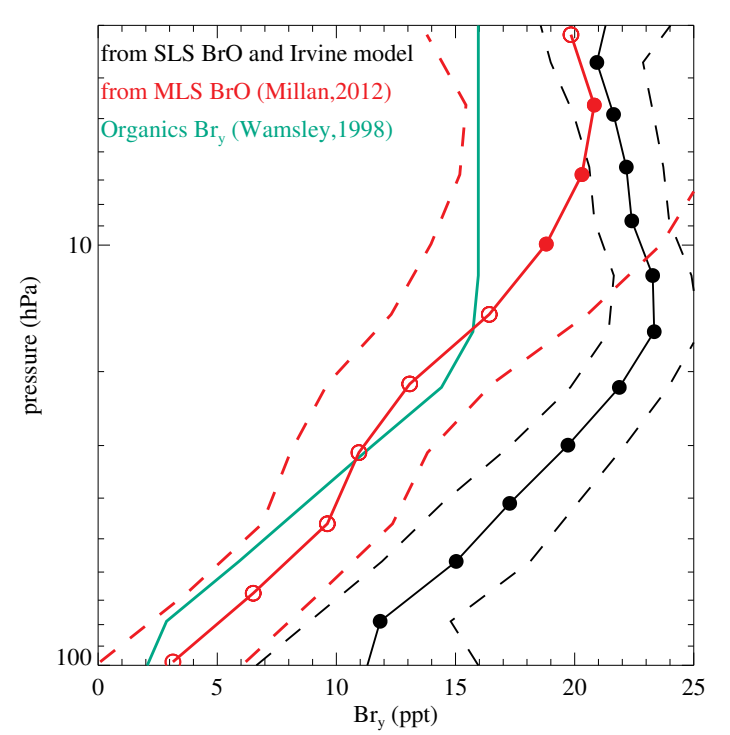

Fig. 9. Comparison of $\mathrm{Br}_{\mathrm{y}}$ mixing ratio scaled from SLS measured $\mathrm{BrO}$ (black) using the UC Irvine photochemical box model against $\mathrm{Br}_{\mathrm{y}}$ inferred from MLS BrO for 2005 (Millán et al., 2012). The range of scientifically useful MLS measurements (10 to $4.6 \mathrm{hPa}$ ) is indicated by solid circles. Uncertainties in $\mathrm{Br}_{\mathrm{y}}$ are indicated by dashed black and dashed red lines for SLS and MLS, respectively. $\mathrm{Br}_{\mathrm{y}}$ from long-lived organic gases from Wamsley et al. (1998) scaled to $16 \mathrm{ppt}$ for an age-of-air of $5 \mathrm{yr}$ (2006) is also plotted (cyan curve).

Closest available JEM-SMILES BrO data, matching season and local time of the SLS balloon flight, are from October 2009. Data presented here are from the JEM/SMILES operational products version 2.3 (Takahashi et al., 2011; Mitsuda et al., 2011).

Figure 10 compares SLS results with daily averaged SMILES BrO profiles (blue lines) for October 12 (49 profiles), 13 (40 profiles), 14 (55 profiles) and 15 (61 profiles) in 2009 with local time between 11:00 and 16:00 and with latitude between $25^{\circ} \mathrm{N}$ and $40^{\circ} \mathrm{N}$. These data are bias-corrected by subtraction of the mean night-time $\mathrm{BrO}$ profile for 12 to 23 October. Local solar times for the selected SMILES overpasses were sufficiently close to the SLS measurement time to make the diurnal correction negligible compared to the combined measurement uncertainty. The RMS variation in the daily averaged SMILES BrO profiles is shown as bluedashed lines in Fig. 10. We find excellent agreement between SMILES and SLS profiles above $20 \mathrm{~km}$ and at other altitudes agreement agreement is well-within the combined uncertanity bounds.

The SCIAMACHY (Bovensmann et al., 1999) instrument on sun-synchronous ENVISAT measures BrO by ultraviolet absorption spectroscopy of limb scattered sunlight. Figure 11 compares SCIAMACHY BrO (red line) from the closest coincident overpass (23 September $2011,32^{\circ} \mathrm{N}$ $100^{\circ} \mathrm{W}$ ) against the SLS BrO profile (black solid circles). 


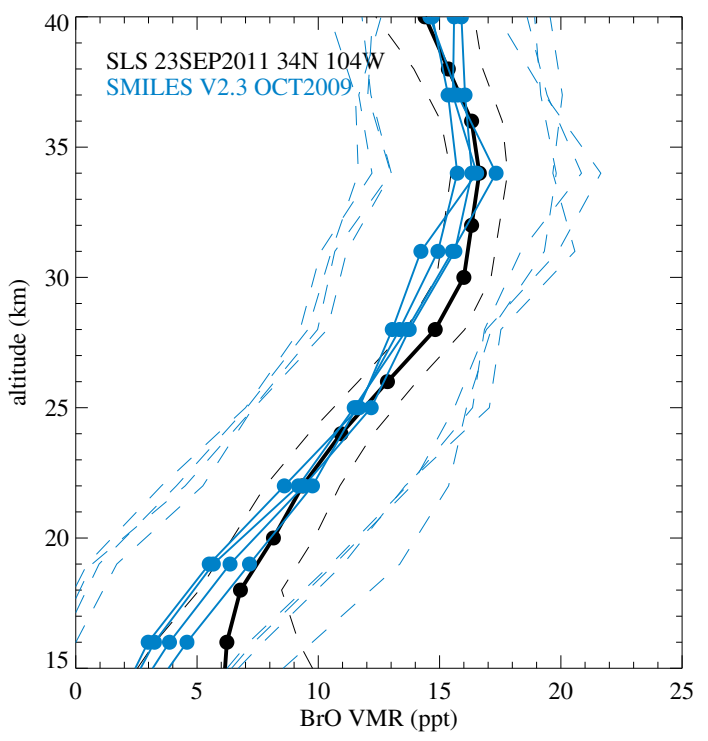

Fig. 10. SLS BrO profile (black dots lines) from the 23 September 2011 balloon flight compared with measurements by the ISS JEM/SMILES instrument in October 2009 (blue-dots-lines). Uncertainty in the SLS BrO profile is shown by the black-dashed lines. SMILES retrieval version 2.3 profiles shown are daily averages (blue-lines) for October 12 (49 profiles), 13 (40 profiles), 14 (55 profiles) and 15 (61 profiles) in 2009 with local time between 11:00 and 16:00 and with latitude between $25^{\circ} \mathrm{N}$ and $40^{\circ} \mathrm{N}$. SMILES data are bias-corrected by subtraction of the mean night-time $\mathrm{BrO}$ profile for October 12 to October 23. Local solar times for the selected SMILES overpasses were sufficiently close to the SLS measurement time to make the diurnal correction negligible compared to the combined measurement uncertainty. The RMS variation in the daily averaged SMILES BrO profiles is shown as blue-dashed lines.

SCIAMACHY BrO uncertainty is larger below $18 \mathrm{~km}$ and above $33 \mathrm{~km}$ due to low measurement response (below 0.65) at those altitudes, and those data are indicated in the plot by open circles. Also shown is the SLS profile adjusted (black open circles) to the local solar time (10:15 a.m.) of the SCIAMACHY overpass. The comparison is shown both in concentration (left panel) and volume mixing ratio (right panel) units. Local solar time correction was approximated using the previously described photochemical box model and a simple linear scaling relation

$\mathrm{BrO}_{t_{\text {SCIA }}}^{\text {meas }}=\frac{\mathrm{BrO}_{t_{\text {SCIA }}^{\text {model }}}^{\text {moris }}}{\mathrm{BrO}_{t_{\mathrm{SLS}}}^{\text {model }}} \mathrm{BrO}_{t_{\mathrm{SLS}}}^{\text {meas }}$

where $\mathrm{BrO}_{t_{\mathrm{SLS}}}^{\text {meas }}$ is the profile measured by SLS, $\mathrm{BrO}^{\text {model }}{ }_{t_{\mathrm{SLS}}}$ is the model profile at the mean local time of SLS measurements, and $\mathrm{BrO}_{t_{\text {SCIA }}}^{\text {meas }}$ is the resulting SLS profile adjusted to the local solar time of the SCIAMACHY daytime overpass. This procedure enables meaningful comparison of measurements made at different local times and solar zenith angles, however, additional uncertainty may enter from uncertainty in the photochemical parameters used in the model

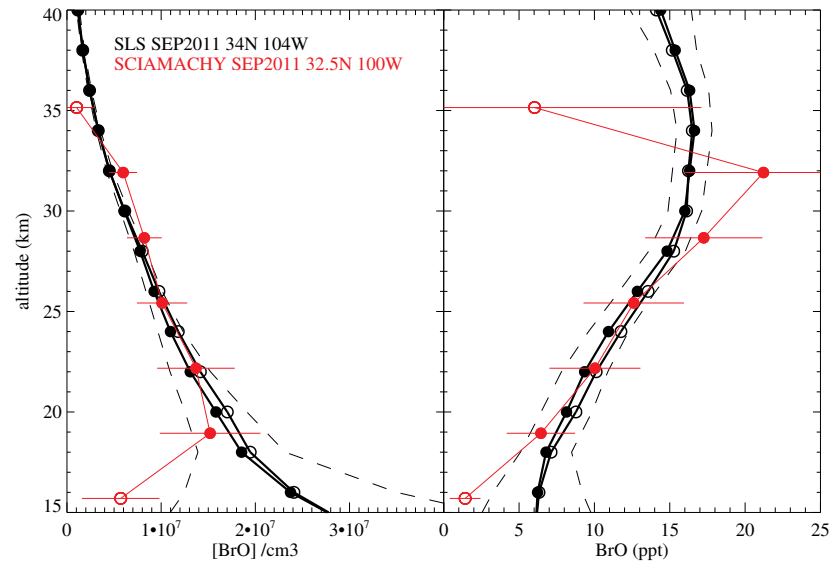

Fig. 11. SLS BrO profile (black-solid circles) from the 23 September 2011 balloon flight compared with SCIAMACHY BrO. Left panel shows the comparison in number density; right panel is the same data plotted as volume mixing ratio. The SCIAMACHY BrO profile (red dots-line) is from the closest coincident overpass (23 September $2011,32^{\circ} \mathrm{N} 100^{\circ} \mathrm{W}$ ). Also shown (black open circles) is SLS profile scaled to the local time (10:15 a.m.) of the SCIAMACHY overpass using the photochemical model described in the text. Uncertainty in the SLS BrO profile is shown by the blackdashed lines. Larger SCIAMACHY BrO uncertainty below $18 \mathrm{~km}$ and above $33 \mathrm{~km}$ is due to low measurement response (below 0.65) at those altitudes and indicated by open circles.

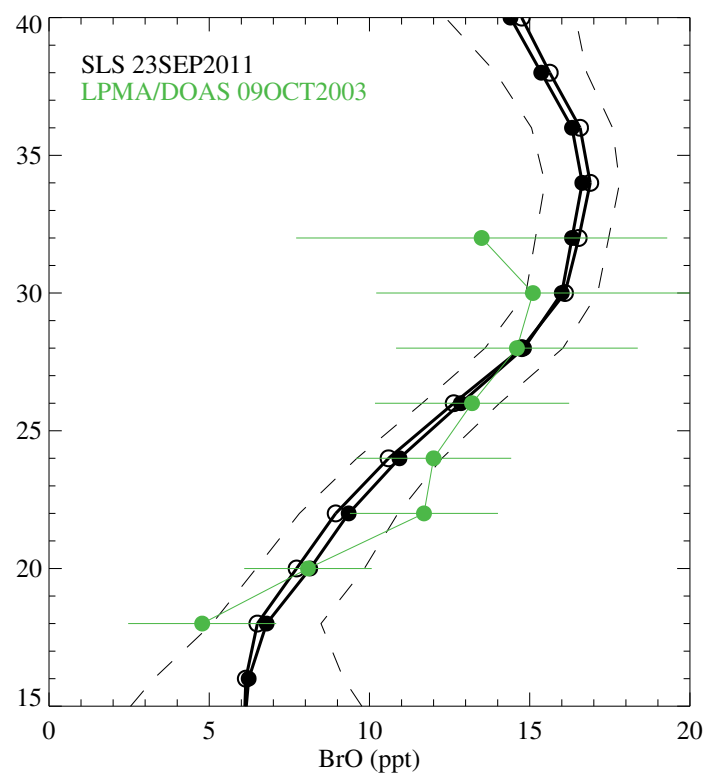

Fig. 12. SLS BrO profile (black-solid circles) from the 23 September 2011 balloon flight compared with a BrO profile (green dotsline) from the LPMA/DOAS instrument (Dorf et al., 2006b). The LPMA/DOAS profile is from a balloon flight launched from Aire sur l'Adour, France $\left(43.7^{\circ} \mathrm{N}, 0.3^{\circ} \mathrm{W}\right)$ on 9 October 2003 . The SLS profile adjusted to the mean local solar time corresponding to the DOAS measurement is also plotted (black open circles). 


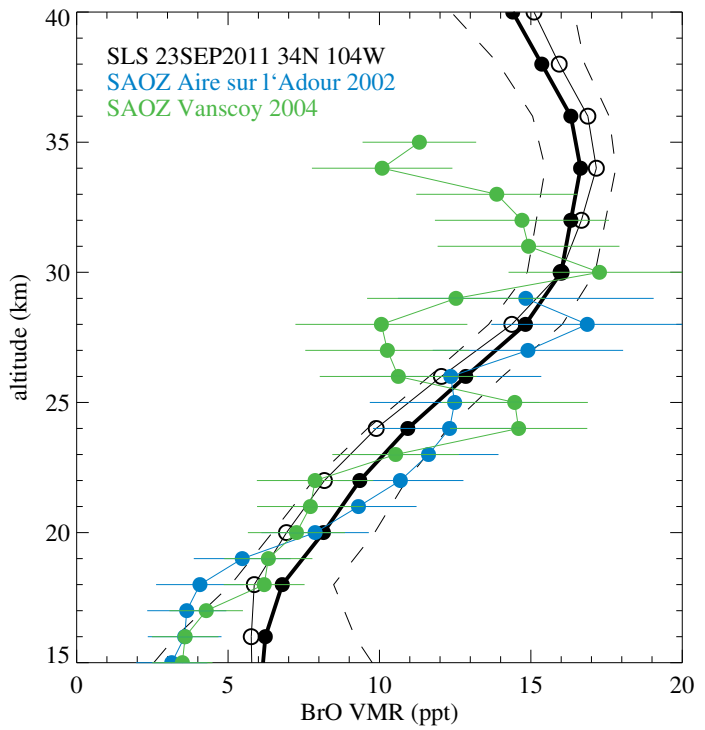

Fig. 13. SLS BrO profile from the 23 September 2011 balloon flight compared with $\mathrm{BrO}$ data from two balloon flights of the SAOZBrO instrument. SAOZ data are from flights launched at Aire sur 1'Adour, France $\left(43.7^{\circ} \mathrm{N}\right)$ (blue dots lines) on 1 October 2002 and at Vanscoy, Canada $\left(52.0^{\circ} \mathrm{N}\right)$ on 25 August 2004 (green dots-lines). $\mathrm{SAOZ}$ measurements were made at solar zenith angles from $81^{\circ}$ $(15 \mathrm{~km})$ to $87^{\circ}(29 \mathrm{~km})$ and from $79^{\circ}(15 \mathrm{~km})$ to $89^{\circ}(35 \mathrm{~km})$ for the October 2002 and August 2004 flights, respectively. The SLS BrO profile scaled to local time corresponding to the mean solar zenith angle during the SAOZ-BrO observations is shown plotted as black open circles-lines.

as discussed by Sioris et al. (2006). Profiles show excellent agreement across the entire altitude range of valid measurements.

For comparison with recent $\mathrm{BrO}$ measurements from balloon, we include in Fig. 12 the $\mathrm{BrO}$ profile from a flight of the LPMA/DOAS (Limb Profile Monitor of the Atmosphere/Differential Optical Absorption Spectrometer) instrument (Pfeilsticker et al., 2000; Dorf et al., 2006a) in October 2003. The balloon was launched from Aire sur l'Adour, France $\left(43.7^{\circ} \mathrm{N}, 0.3^{\circ} \mathrm{W}\right)$, at $10^{\circ}$ higher latitude than that of Ft. Sumner, but at similar season, local time and solar zenith angle.

In Fig. 13, the SLS BrO profile is compared with $\mathrm{BrO}$ profiles from two flights of the SAOZ-BrO balloon instrument. SAOZ-BrO data are from flights launched at Aire sur l'Adour, France $\left(43.7^{\circ} \mathrm{N}\right)$ on 1 October 2002 (blue dots line) and at Vanscoy, Canada $\left(52.0^{\circ} \mathrm{N}\right.$ ) on 25 August 2004 (green dots lines). These SAOZ-BrO data were previously compared with BrO profiles from MLS (Kovalenko et al., 2007), SCIAMACHY Rozanov et al. (2011) and OSIRIS (McLinden et al., 2010). Since SAOZ-BrO makes observations during balloon ascent, solar zenith angles vary with height. During the 1 October 2002, the solar zenith angle was approximately $81^{\circ}$ for measurements at $15 \mathrm{~km}$ to $87^{\circ}$ at $29 \mathrm{~km}$. For

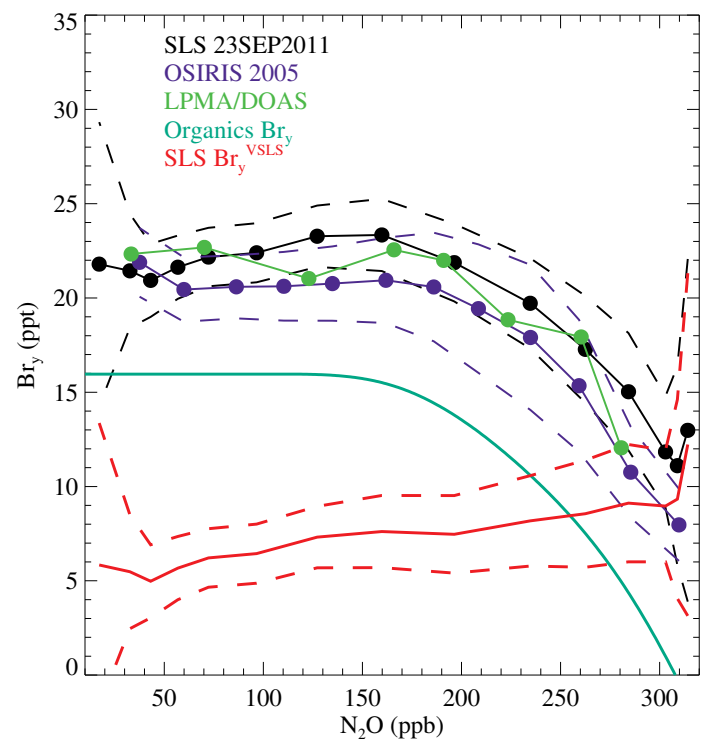

Fig. 14. Correlation of $\mathrm{Br}_{\mathrm{y}}$ mixing ratio inferred from SLS measured $\mathrm{BrO}$ against $\mathrm{N}_{2} \mathrm{O}$ mixing ratio (black). The figure is adapted from Fig. 17 in McLinden et al. (2010). The $\mathrm{Br}_{\mathrm{y}}$ tracer correlation from the Odin-OSIRIS and the Odin/Submillimeter Millimeter Radiometer instruments (McLinden et al., 2010) is shown as purple dots-lines. Odin-OSIRIS data is the monthly mean of a.m. and p.m. observations for the $40^{\circ} \mathrm{S}$ to $40^{\circ} \mathrm{N}$ latitude band. LPMA/DOAS $\mathrm{Br}_{\mathrm{y}}$ correlation (green dots-line) is from a balloon flight in March 2003 from Kiruna, Sweden (Kovalenko et al., 2007). SLS Bry uncertainty range (black-dashed) is the BrO uncertainty scaled by $\mathrm{Br}_{\mathrm{y}} / \mathrm{BrO}$ from the photochemical box model. Abundance of inorganic bromine (cyan) from long-lived source gases is from Wamsley et al. (1998) scaled as in Fig. 8. Estimated $\mathrm{Br}_{\mathrm{y}}$ VSLS abundance (red, uncertainty as red-dashed) is $\mathrm{Br}_{\mathrm{y}}$ minus the estimate of inorganic bromine attributed to long-lived bromine source gases.

the 25 August 2004 flight, solar zenith angles were $79^{\circ}$ at $15 \mathrm{~km}$ to $89^{\circ}$ at $35 \mathrm{~km}$. The SLS BrO profile scaled, using the photochemical model procedure as described above, to local solar time corresponding to the mean solar zenith angle during the SAOZ observations is shown plotted in Fig. 13 as black open circles and line.

LPMA/DOAS and SLS profiles are in good agreement within mutual error extents over the full coincident altitude range. The SLS profile shows excellent agreement with SAOZ-BrO profile from the October 2003 Aire Sur l'Adour balloon flight. SLS BrO is in good agreement with the SAOZ-BrO Vanscoy profile below about $26 \mathrm{~km}$. We note that these four profiles were made over a range of latitude ( $34^{\circ}$ to $52^{\circ} \mathrm{N}$ ), season (summer to autumn), and year (2002-2011) and differences due to $\mathrm{BrO}$ variability are expected. Furthermore, the SAOZ-BrO and LPMA/DOAS observations were made close to the peak stratospheric bromine abundance but the SLS measured after several years of bromine decline (WMO, 2011). 


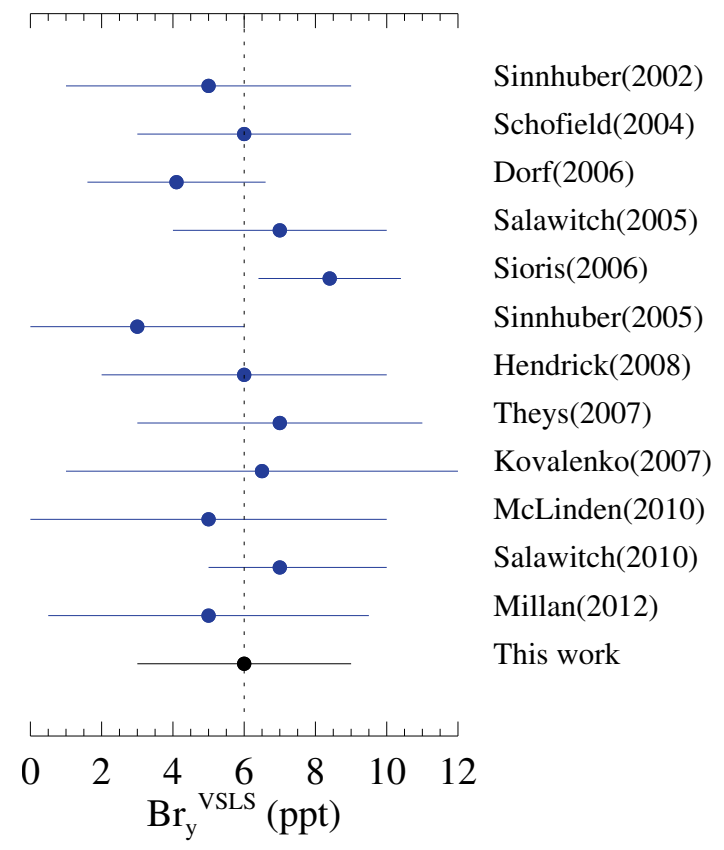

Fig. 15. Adapted from WMO (2011) Tables 1-14 and Millán et al. (2012), summary of recent estimations of the VSLS contribution to stratospheric inorganic bromine $\left(\mathrm{Br}_{\mathrm{y}}^{\mathrm{VSLS}}\right)$ from satellite, groundbased and balloon-borne instruments. Vertical dashed line marks $6 \mathrm{ppt}$, the central values for $\mathrm{Br}_{\mathrm{y}}$ attributed to VSLS.

Figure 14 shows SLS estimated $\mathrm{Br}_{\mathrm{y}}$ (black line) mixing ratio plotted against $\mathrm{N}_{2} \mathrm{O}$ as proxy for age of air. The $\mathrm{N}_{2} \mathrm{O}$ profile is derived from SLS measurements of the $\mathrm{N}_{2} \mathrm{O}$ emission line at $627.8 \mathrm{GHz}$. Plots of $\mathrm{Br}_{\mathrm{y}}$ against a dynamical tracer provide a more meaningful inter-comparison of measurements made at various latitudes and during various seasons.

The $\mathrm{Br}_{\mathrm{y}}-\mathrm{N}_{2} \mathrm{O}$ tracer correlation from the Odin/OSIRIS instrument (McLinden et al., 2010) is shown in Fig. 14. $\mathrm{N}_{2} \mathrm{O}$ data is from the Submillimeter Millimeterwave Radiometer (SMR) on the Odin platform. Odin/OSIRIS curve (purple line) is the monthly mean of AM and PM observations for latitudes between $40^{\circ} \mathrm{S}$ to $40^{\circ} \mathrm{N}$. LPMA/DOAS Bry correlation (green dots-line) from a balloon flight in March 2003 from Kiruna, Sweden $\left(68^{\circ} \mathrm{N}\right)$ is also shown (Kovalenko et al., 2007).

SLS $\mathrm{Br}_{\mathrm{y}}$ uncertainty range (black-dashed) is the $\mathrm{BrO}$ uncertainty scaled by the $\mathrm{Br}_{\mathrm{y}} / \mathrm{BrO}$ ratio from the photochemical box model. Abundance of $\mathrm{Br}_{\mathrm{y}}$ (cyan line) attributed to longlived organic sources is from Wamsley et al. (1998) scaled to the estimated age of air (16 ppt peak abundance) for these observations. Estimated $\mathrm{Br}_{\mathrm{y}}^{\mathrm{VSLS}}$ abundance (red, uncertainty as red-dashed) is $\mathrm{Br}_{\mathrm{y}}$ minus the estimate of inorganic bromine attributed to long-lived bromine source gases.

\section{Conclusions}

Balloon-borne remote sensing submillimeterwave emission measurements of $\mathrm{BrO}$ indicate mid-day abundances ranging from $16 \pm 2 \mathrm{ppt}$ at $34 \mathrm{~km}$ to $6.5 \pm 4$ at $16 \mathrm{~km}$. Total $\mathrm{Br}_{\mathrm{y}}$ abundance, inferred from $\mathrm{BrO}$ and a photochemical model, is $21 \pm 3$ ppt. The inferred $\mathrm{Br}_{\mathrm{y}}$ abundance profile was found to exceed the levels of $\mathrm{Br}_{\mathrm{y}}$ attributable solely to photodecomposition of $\mathrm{CH}_{3} \mathrm{Br}$ and other long-lived source gases throughout the stratosphere. These results are consistent with the view that decomposition of short-lived bromine-containing source gases deposits at least $4 \mathrm{ppt}$ inorganic bromine in the lowermost stratosphere. Inferred $\mathrm{Br}_{\mathrm{y}}^{\mathrm{VSLS}}$ explicitly depends on estimated long-lived source contribution to $\mathrm{Br}_{\mathrm{y}}$ which in turn depends on the tropospheric abundance of source gases which have changed since 1994. Future measurements which include profiles of bromine-containing source gases in the stratosphere and upper troposphere are needed to better quantify $\mathrm{Br}$ chemistry in the lower stratosphere. Figure 15, adapted from WMO (2011) and Millán et al. (2012), compares SLS Br $\mathrm{V}$ VSLS with recent estimations of the VSLS contribution to stratospheric inorganic bromine $\left(\mathrm{Br}_{\mathrm{y}}^{\mathrm{VSLS}}\right)$ from satellite, ground-based and balloon-borne instruments. Vertical dashed line marks $6 \mathrm{ppt}$, the central values for $\mathrm{Br}_{\mathrm{y}}$ attributed to VSLS. Results are in good general agreement with other recent measurements and support the conclusions in WMO (2011).

Acknowledgements. Research at the Jet Propulsion Laboratory, California Institute of Technology, is performed under contract with NASA. We thank and acknowledge the NASA Earth Science Mission Directorate for support of this research. We acknowledge and thank the NASA Columbia Scientific Balloon Facility, Palestine $\mathrm{Tx}$, for balloon launch, telemetry and payload recovery support. We thank the MLS instrument team, the JEM/SMILES instrument and L2 data processing teams for providing the satellite datasets. JEM/SMILES mission is a joint project of Japan Aerospace Exploration Agency (JAXA) and National Institute of Information and Communications Technology (NICT).

Edited by: M. Van Roozendael

\section{References}

Berg, W. W., Crutzen, P. J., Grahek, F. E., Gitlin, S. N., and Sedlacek, W. A.: 1st measurements of total chlorine and bromine in the lower stratosphere, Geophys. Res. Lett., 7, 937-940, 1980.

Bovensmann, H., Burrows, J. P., Buchwitz, M., Frerick, J., Noel, S., Rozanov, V. V., Chance, K. V., and Goede, A. P. H.: SCIAMACHY: Mission objectives and measurement modes, J. Atmos. Sci., 56, 127-150, 1999.

Brinckmann, S., Engel, A., Bönisch, H., Quack, B., and Atlas, E.: Short-lived brominated hydrocarbons - observations in the source regions and the tropical tropopause layer, Atmos. Chem. Phys., 12, 1213-1228, doi:10.5194/acp-12-1213-2012, 2012. 
Brohede, S., McLinden, C. A., Urban, J., Haley, C. S., Jonsson, A. I., and Murtagh, D.: Odin stratospheric proxy $\mathrm{NO}_{\mathrm{y}}$ measurements and climatology, Atmos. Chem. Phys., 8, 5731-5754, doi:10.5194/acp-8-5731-2008, 2008.

Brune, W. H. and Stimpfle, R. M.: In situ measurements of stratospheric reactive trace gases, Adv. Chem., Chapter 5, 232, 133184, doi:10.1021/ba-1993-0232.ch005, 1993.

Daniel, J. S., Solomon, S., Portmann, R. W., and Garcia, R. R.: Stratospheric ozone destruction: The importance of bromine relative to chlorine, J. Geophys. Res.-Atmos., 104, 23871-23880, 1999.

Dorf, M., Bösch, H., Butz, A., Camy-Peyret, C., Chipperfield, M. P., Engel, A., Goutail, F., Grunow, K., Hendrick, F., Hrechanyy, S., Naujokat, B., Pommereau, J.-P., Van Roozendael, M., Sioris, C., Stroh, F., Weidner, F., and Pfeilsticker, K.: Balloon-borne stratospheric $\mathrm{BrO}$ measurements: comparison with Envisat/SCIAMACHY BrO limb profiles, Atmos. Chem. Phys., 6, 2483-2501, doi:10.5194/acp-6-2483-2006, 2006a.

Dorf, M., Butler, J. H., Butz, A., Camy-Peyret, C., Chipperfield, M. P., Kritten, L., Montzka, S. A., Simmes, B., Weidner, F., and Pfeilsticker, K.: Long-term observations of stratospheric bromine reveal slow down in growth, Geophys. Res. Lett., 33, L24803, doi:10.1029/2006GL027714, 2006b.

Drouin, B. J., Miller, C. E., Muller, H. S. P., and Cohen, E. A.: The rotational spectra, isotopically independent parameters, and interatomic potentials for the $\mathrm{X}-1$ (2) $\mathrm{Pi}(3 / 2)$ and $\mathrm{X}-2$ (2) $\mathrm{Pi}(1 / 2)$ states of BrO, J. Molec. Spectrosc., 205, 128-138, 2001.

Goyette, T. M. and DeLucia, F. C.: The Pressure Broadening of the $3_{12} \rightarrow 2_{20}$ Transition of Water Between $80 \mathrm{~K}$ and $600 \mathrm{~K}$, J. Molec. Spectrosc., 143, 346-358, 1990.

Hendrick, F., Johnston, P. V., De Maziere, M., Fayt, C., Hermans, C., Kreher, K., Theys, N., Thomas, A., and Van Roozendael, M.: One-decade trend analysis of stratospheric $\mathrm{BrO}$ over Harestua $\left(60^{\circ} \mathrm{N}\right)$ and Lauder $\left(45^{\circ} \mathrm{S}\right)$ reveals a decline, Geophys. Res. Lett., 35, L14801, doi:10.1029/2008GL034154, 2008.

Houghton, J. T., Taylor, F., and Rodgers, C.: Remote Sounding of atmospheres, Cambridge University Press, New York, NY 10022, USA, 119-140, 1984.

Kikuchi, K., Nishibori, T., Ochiai, S., Ozeki, H., Irimajiri, Y., Kasai, Y., Koike, M., Manabe, T., Mizukoshi, K., Murayama, Y., Nagahama, T., Sano, T., Sato, R., Seta, M., Takahashi, C., Takayanagi, M., Masuko, H., Inatani, J., Suzuki, M., and Shiotani, M.: Overview and early results of the Superconducting Submillimeter-Wave Limb-Emission Sounder (SMILES), J. Geophys. Res.-Atmos., 115, D23306, doi:10.1029/2010JD014379, 2010.

Kovalenko, L. J., Livesey, N. L., Salawitch, R. J., Camy-Peyret, C., Chipperfield, M. P., Cofield, R. E., Dorf, M., Drouin, B. J., Froidevaux, L., Fuller, R. A., Goutail, F., Jarnot, R. F., Jucks, K., Knosp, B. W., Lambert, A., MacKenzie, I. A., Pfeilsticker, K., Pommereau, J. P., Read, W. G., Santee, M. L., Schwartz, M. J., Snyder, W. V., Stachnik, R., Stek, P. C., Wagner, P. A., and Waters, J. W.: Validation of Aura Microwave Limb Sounder BrO observations in the stratosphere, J. Geophys. Res.-Atmos., 112, D24S41, doi:10.1029/2007JD008817, 2007.

Kreycy, S., Camy-Peyret, C., Chipperfield, M. P., Dorf, M., Feng, W., Hossaini, R., Kritten, L., Werner, B., and Pfeilsticker, $\mathrm{K}$.: Atmospheric test of the $J\left(\mathrm{BrONO}_{2}\right) / k \mathrm{BrO}+\mathrm{NO}_{2}$ ratio: implications for total stratospheric Bry and bromine-mediated ozone loss, Atmos. Chem. Phys. Discuss., 12, 27821-27845, doi:10.5194/acpd-12-27821-2012, 2012.

Kühl, S., Pukite, J., Deutschmann, T., Platt, U., and Wagner, T.: SCIAMACHY limb measurements of $\mathrm{NO}_{2}, \mathrm{BrO}$ and OClO. Retrieval of vertical profiles: Algorithm, first results, sensitivity and comparison studies, Adv. Space Res., 42, 1747-1764, 2008.

Masuko, H., Shiotani, M., and the SMILES mission team: JEM/SMILES Mission Plan, version 2.1., Tech. Rep. NASDA/CRL, National Space Development Agency of Japan, and Communications Research Laboratory, http://smiles.nict.go.jp/Mission_Plan/, 2002.

Mitsuda, C., Suzuki, M., Iwata, Y., Manago, N., Naito, Y., Takahashi, C., Imai, K., Nishimoto, E., Hayashi, H., Shiotani, M., Sano, T., Takayanagi, M., and Taniguchi, H.: Current Status of Level 2 Product of Superconducting Submillimeter-Wave LimbEmission Sounder (SMILES), 8716, doi:10.1117/12.898135, SPIE, 2011.

McLinden, C. A., Olsen, S. C., Hannegan, B., Wild, O., Prather, M. J., and Sundet, J.: Stratospheric ozone in 3-D models: A simple chemistry and the cross-tropopause flux, J. Geophys. Res.Atmos., 105, 14653-14665, 2000.

McLinden, C. A., Haley, C. S., Lloyd, N. D., Hendrick, F., Rozanov, A., Sinnhuber, B. M., Goutail, F., Degenstein, D. A., Llewellyn, E. J., Sioris, C. E., Van Roozendael, M., Pommereau, J. P., Lotz, W., and Burrows, J. P.: Odin/OSIRIS observations of stratospheric BrO: Retrieval methodology, climatology, and inferred Br(y), J. Geophys. Res.-Atmos., 115, D15308, doi:10.1029/2009JD012488, 2010.

Millán, L., Livesey, N., Read, W., Froidevaux, L., Kinnison, D., Harwood, R., MacKenzie, I. A., and Chipperfield, M. P.: New Aura Microwave Limb Sounder observations of BrO and implications for $\mathrm{Br}_{\mathrm{y}}$, Atmos. Meas. Tech., 5, 1741-1751, doi:10.5194/amt-5-1741-2012, 2012.

Pfeilsticker, K., Sturges, W. T., Bosch, H., Camy-Peyret, C., Chipperfield, M. P., Engel, A., Fitzenberger, R., Muller, M., Payan, S., and Sinnhuber, B. M.: Lower stratospheric organic and inorganic bromine budget for the Arctic winter 1998/99, Geophys. Res. Lett., 27, 3305-3308, 2000.

Pickett, H. M., Poynter, R. L., Cohen, E. A., Delitsky, M. L., Pearson, J. C., and Muller, H. S. P.: Submillimeter, millimeter, and microwave spectral line catalog, J. Quant. Spectrosc. Ra., 60, 883-890, 1998.

Prather, M.: Catastrophic loss of stratospheric ozone in dense volcanic clouds, J. Geophys. Res.-Atmos., 97, 10187-10191, doi:10.1029/92JD00845, 1992.

Proffitt, M. H. and McLaughlin, R. J.: Fast-response dual-beam uv-absorption ozone photometer suitable for use on stratospheric balloons, Review of Scientific Instruments, 54, 17191728, 1983.

Puksīte, J., Kühl, S., Deutschmann, T., Platt, U., and Wagner, T.: Extending differential optical absorption spectroscopy for limb measurements in the UV, Atmos. Meas. Tech., 3, 631-653, doi:10.5194/amt-3-631-2010, 2010.

Pundt, I., Pommereau, J. P., Chipperfield, M. P., Van Roozendael, M., and Goutail, F.: Climatology of the stratospheric BrO vertical distribution by balloon-borne UV-visible spectrometry, J. Geophys. Res.-Atmos., 107, 4806, doi:10.1029/2002JD002230, 2002. 
Rodgers, C.: Inverse Methods for Atmospheric Sounding: Theory and Practice, World Scientific, Singapore, 2000.

Rosenkranz, P. W.: Water Vapor Microwave Continuum Absorption: a Comparison of Measurements and Results, Radio Sci., 33, 919-928, 1998.

Rozanov, A., Kühl, S., Doicu, A., McLinden, C., Puk,īte, J., Bovensmann, H., Burrows, J. P., Deutschmann, T., Dorf, M., Goutail, F., Grunow, K., Hendrick, F., von Hobe, M., Hrechanyy, S., Lichtenberg, G., Pfeilsticker, K., Pommereau, J. P., Van Roozendael, M., Stroh, F., and Wagner, T.: BrO vertical distributions from SCIAMACHY limb measurements: comparison of algorithms and retrieval results, Atmos. Meas. Tech., 4, 13191359, doi:10.5194/amt-4-1319-2011, 2011.

Salawitch, R. J., Weisenstein, D. K., Kovalenko, L. J., Sioris, C. E., Wennberg, P. O., Chance, K., Ko, M. K. W., and McLinden, C. A.: Sensitivity of ozone to bromine in the lower stratosphere, Geophys. Res. Lett., 32, L05811, doi:10.1029/2004GL021504, 2005.

Sander, S., Friedl, R. R., Barkern, J., Golden, D., Kurylo, M., Wine, P., Abbat, J., Burkholder, J., Moortgaret, C., Huie, R., and Orkin, R. E: Chemical kinetics and photochemical data for use in atmospheric studies, Technical Report, NASA/JPL Publication, 17, 2011.

Schofield, R., Kreher, K., Connor, B., Johnston, P., Thomas, A., Shooter, D., Chipperfield, M., Rodgers, C., and Mount, G.: Retrieved tropospheric and stratospheric BrO columns over Lauder, New Zealand, J. Geophys. Res.-Atmos., 109, D14304, doi:10.1029/2003JD004463, 2004.

Sinnhuber, B.-M., Arlander, D. W., Bovensmann, H., Burrows, J. P., Chipperfield, M. P., Enell, C.-F., Frieß, U., Hendrick, F., Johnston, P. V., Jones, R. L., Kreher, K., Mohamed-Tahrin, N., Müller, R., Pfeilsticker, K., Platt, U., Pommereau, J.-P., Pundt, I., Richter, A., South, A. M., Tørnkvist, K. K., Van Roozendael, M., Wagner, T., Wittrock, F.: Comparison of measurements and model calculations of stratospheric bromine monoxide, J. Geophys. Res. Atmos., 107, 4398, doi:10.1029/2001JD000940, 2002.

Sinnhuber, B., Rozanov, A., Sheode, N., Afe, O., Richter, A., Sinnhuber, M., Wittrock, F., Burrows, J., Stiller, G., von Clarmann, T., and Linden, A.: Global observations of stratospheric bromine monoxide from SCIAMACHY, Geop. Res. Lett., 32, L20810, doi:10.1029/2005GL023839, 2005.

Sioris, C. E., Kovalenko, L. J., McLinden, C. A., Salawitch, R. J., Van Roozendael, M., Goutail, F., Dorf, M., Pfeilsticker, K., Chance, K., von Savigny, C., Liu, X., Kurosu, T. P., Pommereau, J. P., Bosch, H., and Frerick, J.: Latitudinal and vertical distribution of bromine monoxide in the lower stratosphere from Scanning Imaging Absorption Spectrometer for Atmospheric Chartography limb scattering measurements, J. Geophys. Res.Atmos., 111, D14301, doi:10.1029/2005JD006479, 2006.

Stachnik, R. A., Hardy, J. C., Tarsala, J. A., Waters, J. W., and Erickson, N. R.: Submillimeter wave heterodyne measurements of stratospheric $\mathrm{ClO}, \mathrm{HCl}, \mathrm{O}_{3}$, and $\mathrm{HO}_{2}-1$ st results, Geophys. Res. Lett., 19, 1931-1934, 1992.

Stachnik, R. A., Salawitch, R., Engel, A., and Schmidt, U.: Measurements of chlorine partitioning in the winter Arctic stratosphere, Geophys. Res. Lett., 26, 3093-3096, 1999.
Takahashi, C., Ochiai, S., and Suzuki, M.: Operational Retrieval Algorithms for JEM/SMILES Level 2 Data Processing System, J. Quant. Spectrosc. Radiat. Transf., 111, 160-173, doi:10.1016/j.jqsrt.2009.06.005, 2010.

Theys, N., Van Roozendael, M., Hendrick, F., Fayt, C., Hermans, C., Baray, J.-L., Goutail, F., Pommereau, J.-P., and De Maziére, M.: Retrieval of stratospheric and tropospheric BrO columns from multi-axis DOAS measurements at Reunion Island $(21 \circ \mathrm{S}$, 56o E), Atmos. Chem. Phys., 7, 4733-4749, doi:10.5194/acp-74733-2007, 2007.

Toon, G. C.: The JPL MkIV Interferometer, Opt. Photonic News, 2, 19-21, 1991.

Wamsley, P. R., Elkins, J. W., Fahey, D. W., Dutton, G. S., Volk, C. M., Myers, R. C., Montzka, S. A., Butler, J. H., Clarke, A. D., Fraser, P. J., Steele, L. P., Lucarelli, M. P., Atlas, E. L., Schauffler, S. M., Blake, D. R., Rowland, F. S., Sturges, W. T., Lee, J. M., Penkett, S. A., Engel, A., Stimpfle, R. M., Chan, K. R., Weisenstein, D. K., Ko, M. K. W., and Salawitch, R. J.: Distribution of halon-1211 in the upper troposphere and lower stratosphere and the 1994 total bromine budget, J. Geophys. Res.-Atmos., 103, 1513-1526, 1998.

Ward, J. S.: Observations of Carbon Monoxide in the Starburst Galaxy M82 with a $690 \mathrm{GHz}$ Wide Spectral Bandwidth Receiver, Ph.D. thesis, California Institute of Technology, CA, USA, 2003.

Ward, J. S., Zmuidzinas, J., Harris, A. I., and Isaak, K. G.: A (CO)C-12 $J=6-5$ map of M82: The significance of warm molecular gas, Astrophys. J., 587, 171-185, 2003.

Waters, J. W., Froidevaux, L., Harwood, R. S., Jarnot, R. F., Pickett, H. M., Read, W. G., Siegel, P. H., Cofield, R. E., Filipiak, M. J., Flower, D. A., Holden, J. R., Lau, G. K., Livesey, N. J., Manney, G. L., Pumphrey, H. C., Santee, M. L., Wu, D. L., Cuddy, D. T., Lay, R. R., Loo, M. S., Perun, V. S., Schwartz, M. J., Stek, P. C., Thurstans, R. P., Boyles, M. A., Chandra, K. M., Chavez, M. C., Chen, G. S., Chudasama, B. V., Dodge, R., Fuller, R. A., Girard, M. A., Jiang, J. H., Jiang, Y. B., Knosp, B. W., LaBelle, R. C., Lam, J. C., Lee, K. A., Miller, D., Oswald, J. E., Patel, N. C., Pukala, D. M., Quintero, O., Scaff, D. M., Van Snyder, W., Tope, M. C., Wagner, P. A., and Walch, M. J.: The Earth Observing System Microwave Limb Sounder (EOS MLS) on the Aura satellite, IEEE Trans. Geosci. Remote Sens., 44, 1075-1092, 2006.

Werthimer, D.: The CASPER collaboration for high-performance open source digital radio astronomy instrumentation, in: General Assembly and Scientific Symposium, 2011 XXXth URSI, 1-4, doi:10.1109/URSIGASS.2011.6051282, 2011.

WMO: Scientific Assessment of Ozone Depletion: 2010, Global Ozone Research and Monitoring Project-Report No. 52, World Metrological Organization, Geneva, Switzerland, 2011.

Woyke, T., Muller, R., Stroh, F., McKenna, D. S., Engel, A., Margitan, J. J., Rex, M., and Carslaw, K. S.: A test of our understanding of the ozone chemistry in the Arctic polar vortex based on in situ measurements of $\mathrm{ClO}, \mathrm{BrO}$, and $\mathrm{O}_{3}$ in the 1994/1995 winter, J. Geophys. Res.-Atmos., 104, 18755-18768, 1999.

Yamada, M. M., Kobayashi, M., Habara, H., Amano, T., and Drouin, B. J.: Submillimeter-wave measurements of the pressure broadening of BrO, J. Quant. Spectrosc. Ra., 82, 391-399, 2003.

Zmuidzinas, J.: Quasi-optical slot antenna SIS Mixers, IEEE Trans. Microw. Theory Techn., 40, 1797-1804, 1992. 